\title{
Evolution of marine storminess in the Belgian part of the North Sea
}

\author{
D. Van den Eynde ${ }^{1}$, R. De Sutter ${ }^{2,3}$, and P. Haerens ${ }^{2}$ \\ ${ }^{1}$ Management Unit of the North Sea Mathematical Models, Royal Belgian Institute of Natural Sciences, Brussels, Belgium \\ ${ }^{2}$ International Marine and Dredging Consultants, Antwerp, Belgium \\ ${ }^{3}$ Ghent University, Ghent, Belgium
}

Correspondence to: D. Van den Eynde (d.vandeneynde@mumm.ac.be)

Received: 28 April 2011 - Revised: 24 October 2011 - Accepted: 7 November 2011 - Published: 10 February 2012

\begin{abstract}
Severe storms have affected European coast lines in the past but knowledge on changes in storminess for the last decades is still sparse. Climate change is assumed to be a main driving factor with the potential to induce changes on the intensity, duration and frequency of powerful marine storms, including a long-term influence on peak wind speeds, surges and waves. It is, therefore, important to investigate whether in the last decades changes in the magnitude of storms, their duration and frequency could be observed. Understanding trends in storminess in the last decades will help to better prepare coastal managers for future events, taking into account potential changes on storm occurrence and magnitude to improve planning of mitigation and adaptation strategies. The purpose of this study was to focus on the evolution of extreme wind conditions, wave height and storm surge levels in the North Sea Region, especially in the Belgian part of the North Sea (BPNS). Based on the analysis performed it is concluded that no clear trend can be observed for the occurrence of significant increasing extreme wind speeds over the BPNS. Furthermore, one can conclude that not enough scientific evidence is available to support scenarios with increased wave height or storminess.
\end{abstract}

\section{Introduction}

The effects of climate change on marine systems are manifold (Van den Eynde et al., 2011). This paper deals with a number of highly relevant determinants of marine storminess and assesses the changes in the storminess character at the Belgian coast related to the driving factors sea water level, wind and wave climate. There is no unique definition for storminess. A storm is characterised by its intensity, frequency and duration of characteristic storm properties
(MICORE, 2009). In some studies wind speed is used as the indicator and in other studies storm surge or air surface pressure is used. Recently Haerens et al. (2011) have used five indicators to provide a first estimate of the storm threshold inducing significant morphological changes along the sandy beaches in Belgium. Based on their investigations, it was found that marine storms that cause significant morphological impact along major parts of the Belgian coast line should be characterised by a maximum significant offshore wave height higher than $4 \mathrm{~m}$, maximum water level above $+5 \mathrm{~m}$ with reference to the reference level "Tweede Algemene Waterpassing" (TAW), storm duration longer than $12 \mathrm{~h}$, an induced wave energy above $6.5 \times 10^{5} \mathrm{~J} \mathrm{~m}^{-2}$ and wind direction between $\mathrm{W}$ and NW.

When examining climate change influence on storminess, the use of different indicators, hence data, will undoubtedly lead to different interpretations of storminess change. While the most obvious and important effect of change in storminess would be the impact on coastal safety, other activities such as marine transport, harbour logistics, fisheries and coastal tourism also could be heavily impacted. Despite the obvious importance of storminess for safety and economy, little is quantitatively known of changes that have occurred in storminess because of climate (Smits et al., 2005).

Sea level rise is an important indicator of climate change in coastal regions. It increases the likelihood of coastal erosion, land-water salt intrusion and endangers coastal ecosystems. Changes in mean sea level will influence the extreme water levels, propagation and dissipation of tidal waves and storm waves. Changes in extreme water levels are directly relevant to the assessment of changes in coastal storminess. Changes in sediment transport cycles will occur and, together with the changing hydrodynamic conditions, will cause secondary effects like the siltation of sea harbours and fair channels. 

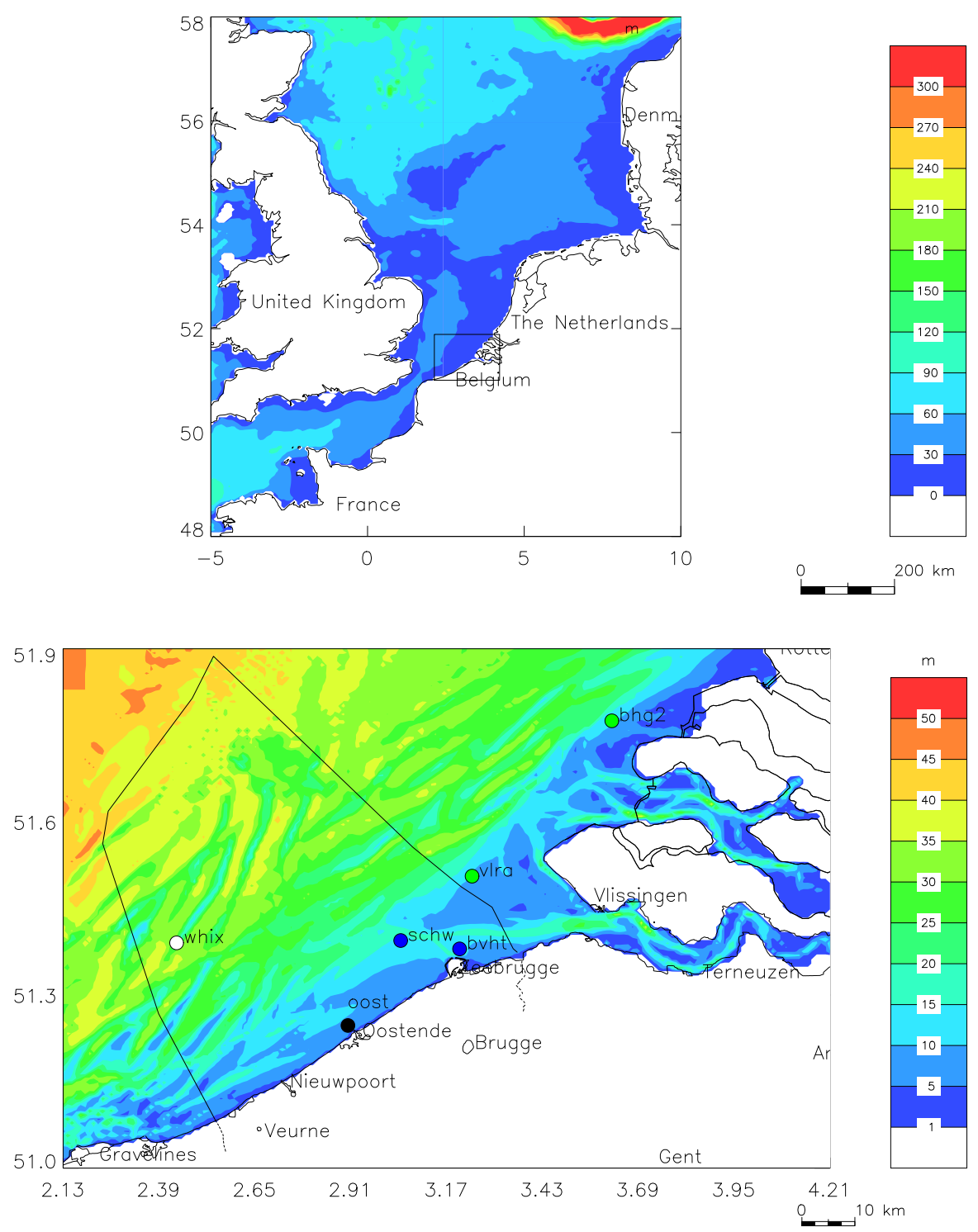

Fig. 1. Above: bathymetry of the southern North Sea with the indication of the Belgian Part of the North Sea (BPNS); Below: Bathymetry of the BPNS with the position of the stations where time series were analysed. Following abbreviations are used: whix: Westhinder; oost: Oostende; schw: Scheur West; bvht: Bol van Heist; vlra: Vlakte van de Raan; bhg2: Brouwershavensegat 2. The colours indicate which data were analysed: black: water elevation; white: wind speed; purple: significant wave height; green: wind speed and significant wave height.

Wind speed and the duration of storms can also be used as an indicator of change in storminess due to global climate changes. Waves are important, e.g. for coastal erosion, changes in sediment transport or for oil slick dispersion.

This paper reports on the state-of-the-art climate change impact assessment on the marine hydrodynamic environment of the BPNS. More specifically, it deals with wind, waves and water level, but focuses on storm conditions and, hence, extreme conditions for these parameters.

\section{Methods}

Evidence of change, due to climate modifications in wind, waves and water level were analysed using statistical analysis of long time series. Historical datasets were made available by different government institutions. Mean sea level data were obtained from the Agency of Marine and Coastal Services (MDK) and were downloaded from the Permanent Service for Mean Sea Level (PSMSL, http://www.pol.ac.uk/ $\mathrm{psms} /$ /datainfo). Wind and wave data were obtained from the Agency of Marine and Coastal Services and from the Hydro Meteo Centrum Zeeland. We also used meteorological fields 
from the Norwegian Meteorological Institute. The position of the stations that were used in the analysis are shown in Fig. 1. The data that were used in the analysis are also summarised in Table 1.

This state-of-the-art review is based on our own analysis and literature data. To back up this analysis, reference will be made to recent findings in neighbouring North Sea countries.

\section{Results}

\subsection{Sea level}

\subsubsection{Introduction}

There is a consensus that global sea level is rising, although local differences are possible. In Europe, increases in sea level are measured between 0.8 and $3.0 \mathrm{~mm}$ per year (European Commission, 2006). This is partly due to thermal expansion (volume increase with increasing temperature) and to the transport of melting ice on land to the sea.

More information about causes, reported changes at the global level and evolution of sea level on a European scale can be found in MIRA (2008). Both mean sea level and extreme water levels will rise. Changes in sea level and storminess will increase the height of storm surges and the risk of coastal flooding. In addition, subsidence and rising of land will alter the relative height of extreme water events measured on land.

\subsubsection{Mean sea level}

A time series of yearly mean sea level values at the station Oostende (location shown in Fig. 1), with reference to TAW, has been used to investigate how mean sea level evolved during the last $80 \mathrm{yr}$. Time series of yearly mean sea levels were prepared from monthly and yearly values from the PSMSL, from hourly water level values from the MDK and from high and low water levels from the MDK. All these data were used to construct time series of yearly mean sea levels, taking into account data gaps and differences in reference levels.

The final time series of yearly mean sea level values is presented on Fig. 2. Values vary between $2.172 \mathrm{~m}$ (observed in 1929) and $2.357 \mathrm{~m}$ (observed in 2001). Even though the year to year variability is high, it is quite clear that mean sea level has risen over the period of interest. This is further confirmed by the fact that the mean value, equal to $2.257 \mathrm{~m}$, is well below the latest mean sea level value, equal to $2.294 \mathrm{~m}$, computed by the MDK over the period 1982.3-2000.

Using conventional linear regression, sea level rise was computed to be $1.69 \mathrm{~mm} \mathrm{yr}^{-1}$, a value larger than those reported in previous studies (Van Cauwenberghe, 1995, 1999) but very close to the value $\left(1.70 \mathrm{~mm} \mathrm{yr}^{-1}\right)$ more recently estimated by the Intergovernmental Panel on Climate Change (IPCC) (Bindoff et al., 2007) for the global average sea level rise during the 20th century. Other models (piecewise linear, 3rd order polynomial) in which the sea level rise is allowed to vary in time (either by step or continuously) were also applied in addition to the simple linear regression model. When using a piecewise linear regression (as proposed, e.g. by Metrevelli et al., 1980), an inflexion point was found in 1992, with a sea level rise after 1992 equal to $4.41 \mathrm{~mm} \mathrm{yr}^{-1}$. This value is close to the global average value of $4.0 \mathrm{~mm} \mathrm{yr}^{-1}$ estimated by Holgate and Woodworth (2004) over the period January 1993 to December 2002. Although there is no statistical indication, using the Akaike Information Criterion, that the other models fit the data better than the simple linear regression, it can be noted that an acceleration in sea level rise is predicted by the higher order models. An increase in sea level rise over the last decades was put forward by Holgate and Woodworth (2004) and by Church and White (2006). Via a simple extrapolation of the different (linear up to 3rd order polynomial) regression lines, mean sea level in Belgium would rise between about 0.2 and $2.0 \mathrm{~m}$ by 2100 .

In the Netherlands, close to the Belgian part of the North Sea, high-end climate change scenarios for flood protection are under further investigation. Recent information (Katsman et al., 2009) estimates local sea level rises between $0.5 \mathrm{~m}$ and $1.15 \mathrm{~m}$ or between $0.05 \mathrm{~m}$ and $1.25 \mathrm{~m}$ for 2100 , depending on the adopted impact of elastic and gravity effects. For 2200 these ranges become 1.5 to $4 \mathrm{~m}$ and 0.5 to $4 \mathrm{~m}$, respectively. Uncertainty ranges were recently given for the first time in the United Kingdom, including uncertainty in current models and emission scenarios. They project the likely range of absolute sea level rise around the United Kingdom to range from $11.6 \mathrm{~cm}$ to $75.8 \mathrm{~cm}$ (the 5 th percentile and the 95th percentile) by 2095 (Lowe et al., 2009).

\subsubsection{Surge level}

In Ullmann and Monbaliu (2010), long term measurements (since 1925) of sea level, sea surges and wind speeds along the Belgian coast, were analysed and related to atmospheric circulation patterns. The sea surges were calculated by subtracting the corresponding astronomical tides from the daily maximum sea level heights. A rising trend of $3 \mathrm{~mm} \mathrm{yr}^{-1}$ can be observed.

Extreme surge heights are defined in Ullmann and Monbaliu (2010) as the surge heights above the 99th percentile of sea surge height at Oostende (period 1925-2000), which is equal to $65 \mathrm{~cm}$. Also the wintertime 99th percentile of sea surge at Oostende shows a slight (linear) increase, with a value of $+1 \mathrm{~mm} \mathrm{yr}^{-1}(p>99 \%)$ during the period 19252000. Based on an analysis of the correlation between the surge level at Oostende and different weather patterns (atmospheric circulation patterns over the Northern Atlantic) for the period $1925-2000$, it is shown that $70 \%$ of the surge levels greater than $65 \mathrm{~cm}$ are the result of one specific weather pattern, known as the "Atlantic Ridge" pattern. This pattern is characterised by lower atmospheric pressures over the Baltic Sea and Scandinavia and high atmospheric pressures 
Table 1. Position of the stations and data used in the analysis.

\begin{tabular}{|c|c|c|c|c|}
\hline Station & Abbreviation & Type of data & Source & Period \\
\hline Oostende & oost & Water elevation (m) & $\begin{array}{l}\text { Agency of Marine and Coastal Services } \\
\text { Permanent Service for Mean Sea Level }\end{array}$ & 1927-2006 \\
\hline Westhinder & whix & Wind speed $\left(\mathrm{m} \mathrm{s}^{-1}\right)$ & Agency of Marine and Coastal Services & 1994-2007 \\
\hline Brouwershavensegat 2 & bhg2 & Wind speed $\left(\mathrm{m} \mathrm{s}^{-1}\right)$ & Hydro Meteo Centrum Zeeland & $1980-2007$ \\
\hline Vlakte van de Raan & vlra & Wind speed $\left(\mathrm{m} \mathrm{s}^{-1}\right)$ & Hydro Meteo Centrum Zeeland & $1988-2007$ \\
\hline Westhinder & whid & Wind speed $\left(\mathrm{m} \mathrm{s}^{-1}\right)$ & Norwegian Meteorological Institute (model results) & $1955-2006$ \\
\hline Bol van Heist & bvht & Significant wave height (m) & Agency of Marine and Coastal Services & 1981-2007 \\
\hline Brouwershavensegat 2 & bhg2 & Significant wave height (m) & Hydro Meteo Centrum Zeeland & 1980-2007 \\
\hline Vlakte van de Raan & vlra & Significant wave height (m) & Hydro Meteo Centrum Zeeland & 1985-2007 \\
\hline Scheur West & schw & Significant wave height (m) & Hydro Meteo Centrum Zeeland & 1985-2007 \\
\hline
\end{tabular}

over the Azores, resulting in a north-westerly wind over the Belgian coast. Although the frequency of the Atlantic Ridge weather pattern did not change over the period, it was shown that the increase in surge levels at the Belgian coast is a result of a corresponding increase in air pressure above the North Atlantic Ocean and the Azores (Ullmann and Monbaliu, 2010).

On the other hand, $100 \mathrm{yr}$ data of storm surge variations were analysed for different coastal stations in the North Sea by Bijl et al. (1999). They showed that for the stations in the southern North Sea, a considerable natural variability at a decadal time scale exists and that there appears to be a tendency towards a weakening in storm activity, which is, however, not significant. In the stations in the German Bight more variability exists with no indication of weakening of the storm climate.

In Ullmann et al. (2009) and Ullmann and Monbaliu (2009), the long-term variability of the extreme surges along the Belgian coast were predicted for the next century. The predictions were, amongst others, based on 17 ensemble runs for the sea level pressure, simulated from 1950 to 2100, by the ECHAM/MPI-OM global climate model (Jungclaus et al., 2006) under the A1B climate change scenario of the IPCC Special Report on Emission Scenario (IPCC, 2001), which were executed in the framework of the ESSENCE project (Sterl et al., 2008). Based on a stationary sea level pressure over the Baltic Sea in the global climate model predictions, no significant changes in the yearly $90 \%$ surges were expected in the 21 th century. This agrees with other studies, focusing on the Dutch coast, which foresee no significant changes in the sea surges until the end of the 21th century (Van den Hurk et al., 2007; Debenard and Roed, 2008).

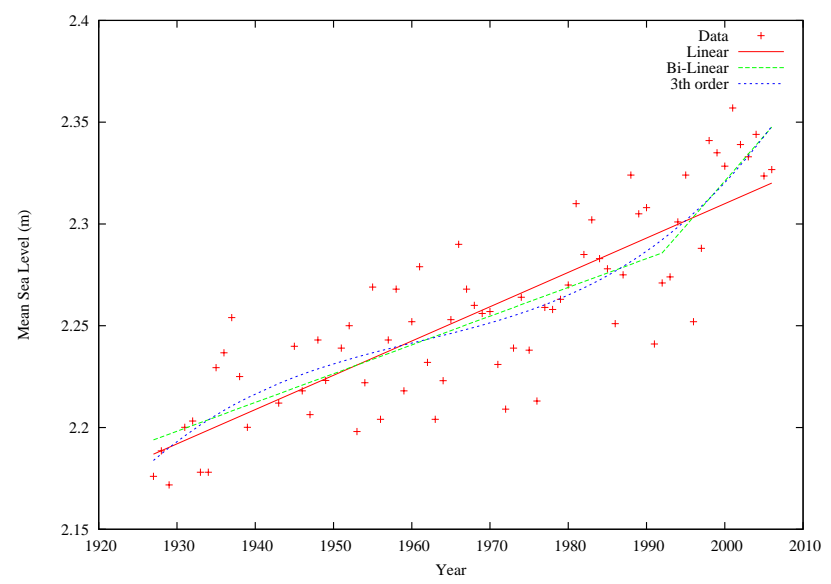

Fig. 2. Time series of yearly mean sea level MSL (TAW) at Oostende for the period 1927-2006.

\subsection{Wind}

\subsubsection{Introduction and average values}

A statistical analysis was carried out using available wind measurements in the Belgian part of the North Sea for the longest possible period. A first set of analysed data was measured at Westhinder by the MDK over the period 1994-2007. A second set of measurements was obtained from the Hydro Meteo Centrum Zeeland (http://www.hmcz.nl) for Brouwershavensegat 2 (1980-2007) and Vlakte van de Raan (19882007). Furthermore, operational model wind field data for atmospheric pressure and wind vectors were obtained from the Norwegian Meteorological Institute (DNMI) for the period 1955 to 2006 (Reistad and Iden, 1998). A time series for the station Westhinder was constructed using these wind fields. The position of these measuring stations is indicated in Fig. 1. It is clear that the measurements and the model 
results are different sources of data and may not be consistent with each other. Furthermore, less variability is included in the model results, which have larger time steps than the measurements. However, the fact that the model results extend over a much longer period, convinced the authors to include this time series in the analysis. The results have to be considered with the necessary precautions.

Parameters were averaged monthly to obtain uniform time series. These time series were then split in a long-term trend, a seasonal cycle and a residue, following methods proposed in the NOWESP project (Visser et al., 1996). The long-term trend was calculated on the basis of a moving average filter with a period of 48 months. Gaps in the monthly mean time series were interpolated, taking into account the long-term trend and the seasonal cycle.

In the long-term trend of the DNMI meteorological forecasts of the wind speed at Westhinder, an increase in monthly mean wind speed was observed between 1955 and 1968, after which a small decrease of monthly mean wind speed occurs. This decrease in wind speed is still more apparent since the period 1990-1995. However, over the entire period 19552006, no clear increasing or decreasing trend is detected in the average wind speed. The time series at the other measuring stations are too short to give conclusive answers.

On the other hand, in Siegismund and Schrum (2001) data from the NCEP/NCAR reanalysis were used to analyse wind speed and wind direction during the 1958-1997 period over the entire North Sea. A wind speed increase of about $10 \%$ was found. Measurements of the cubed wind speed in Utsira (Norway) also show an increasing trend over the 19502000 period (OSPAR Commission, 2000). Using station data for 1962-2002, Smits et al. (2005), however, concluded that wind speed over the Netherlands in that period decreased by a value of between 5 and $10 \%$ per decade. They pointed out that inhomogeneity in the reanalysis data was the main cause of the discrepancy. Regional differences could be important, as shown by Weisse et al. (2005), using NCEP/NCAR data to force a regional climate model for the North Atlantic Ocean. They found important regional differences with opposing trends above and below $45^{\circ} \mathrm{N}$.

Concerning the wind direction, an increase in southwestern winds was found over the last decades. This is visible in the larger increase in winds towards the north. When looking at the variation in the wind density function, as defined in Siegismund and Schrum (2001), an increase in frequency or in intensity of west-south-western winds was also visible over decades. This agrees with the results obtained in Siegismund and Schrum (2001). The analysis further showed that the strongest winds occur in the months of November to February, although no clear seasonal difference in wind direction occurred.

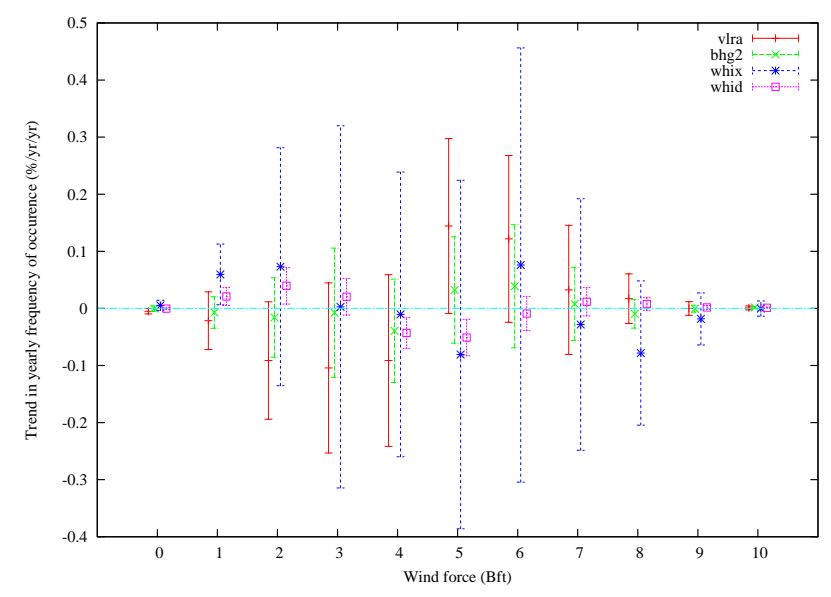

Fig. 3. Trend in the yearly frequency of occurrence for the difference in wind forces. vlra: Vlakte van de Raan; bhg2: Brouwershavensegat 2; whix: Westhinder; whid: Westhinder DNMI data. The error bars give the $95 \%$ confidence interval.

\subsubsection{Trends in changes of duration of extreme wind conditions}

Since the emphasis of this paper is on increased storminess on the BPNS, the trend in the occurrence of high wind speeds was analysed in more detail. The trends in the yearly frequencies of occurrence of difference in wind forces (in Beaufort) were analysed for the four stations. To avoid results being influenced by missing values, data within a year must be uniformly spread. Therefore, it is necessary that a minimum of $5 \%$ of the data are found in at least 9 months of the year. If more than 3 months contain too little data, the year was skipped in the trend calculations. The results are presented in Fig. 3.

No clear trend could be observed. In general, the occurrence of lower wind speeds seems to decrease, while winds of 5 or $6 \mathrm{Bft}$ seem to increase in most stations. However, most of these trends are not statistically significant $(95 \%$ level), see Table 2 for significant trends. Therefore, one can conclude that there is no scientific evidence of a trend in frequency of extreme wind conditions over the period.

The duration of the storms were also analysed. The duration of a storm with a certain wind force was defined as the period during which the wind speed is continuously above a threshold level. If two storms are less then one day apart, it is assumed that the second storm is in fact the continuation of the first storm and the duration of the storm is then defined as the period from the start of the "first storm" until the end of the "second storm". In Fig. 4 the trend in the duration of the storms are presented, together with the $95 \%$ confidence intervals.

No clear conclusions can be drawn with respect to the storm duration. The duration of the storms above $6 \mathrm{Bft}$ seems to be increased, but these trends are not statistically 
Table 2. Significant trends in the yearly frequency of occurrence for the difference in wind forces. vlra: Vlakte van de Raan; bhg2: Brouwershavensegat 2; whid: Westhinder DNMI data. $R^{2}$ : coefficient of determination.

\begin{tabular}{lrrrrrr}
\hline Station & Bft & $\begin{array}{r}\text { Mean } \\
\left(\% \mathrm{yr}^{-1}\right)\end{array}$ & $\begin{array}{r}\text { Trend } \\
\left(\% \mathrm{yr}^{-2}\right)\end{array}$ & $\begin{array}{r}\text { Confidence interval } \\
\left(\% \mathrm{yr}^{-2}\right)\end{array}$ & P-Value & $\begin{array}{r}R^{2} \\
(\%)\end{array}$ \\
\hline bhg2 & 10 & 0.0083 & 0.00162 & 0.00156 & 0.042 & 17.50 \\
vlra & 0 & 0.1111 & -0.0049 & 0.0047 & 0.040 & 23.66 \\
whix & 1 & 1.825 & 0.0595 & 0.0531 & 0.032 & 37.70 \\
whid & 1 & 3.221 & 0.02090 & 0.01564 & 0.001 & 12.59 \\
& 2 & 11.437 & 0.03960 & 0.00748 & 0.017 & 10.92 \\
& 4 & 24.196 & -0.04305 & 0.02741 & 0.003 & 16.58 \\
& 5 & 21.662 & -0.05116 & 0.03195 & 0.003 & 17.15 \\
& 10 & 0.0327 & 0.00116 & 0.00105 & 0.031 & 8.99 \\
\hline
\end{tabular}

significant (95\% level). The only significant increase is the increase in the duration of storms of $7 \mathrm{Bft}$ at Westhinder (DNMI data) and in the duration of the storms of $8 \mathrm{Bft}$ at Vlakte van de Raan.

\subsubsection{Trends in frequency of storms}

Finally, also the number of storms, as defined above in Sect. 3.2.2, was analysed. The analysis showed that only a significant $(95 \%)$ increase in the number of storms of $8 \mathrm{Bft}$ was found at Brouwershavensegat 2, while a significant $(95 \%)$ decrease in the number of storms of $6 \mathrm{Bft}$ was detected at Westhinder. At Vlakte van de Raan, no significant trends in the number of storms was found. The DNMI model wind speed at Westhinder showed an (significant $95 \%$ level) increase of storms of $8 \mathrm{Bft}$ and a decrease of storms of $6 \mathrm{Bft}$ over the period. Overall, one can again conclude that no statistically evidence is found for trends in the frequency of storms.

It is worth noting that some contradicting results can also be found in literature. Via a regional climate model, Weisse et al. (2005) reached the conclusion that there is a rising trend in the occurrence of storms for the period 1958 to 1990 in the Southern North Sea, followed by a decrease in the occurrence of storms since 1990-1995. Smits et al. (2005) analysed a number of high quality wind data in the Netherlands. These results indicate a continuous reduction in the number of storms in the Netherlands since 1962 to 2002.

\subsection{Waves}

\subsubsection{Introduction and significant wave height}

A statistical analysis of the measured wave heights in the Belgian Part of the North Sea has also been carried out. Wave measurements were made by the MDK at the Bol van Heist (period 1978-2007) and by the Hydro Meteo Centrum Zeeland at Brouwershavensegat 2 for the period 1980-2007, and Vlakte van de Raan and Scheur West, both for the period 1985-2007. The position of these stations is shown in Fig. 1.

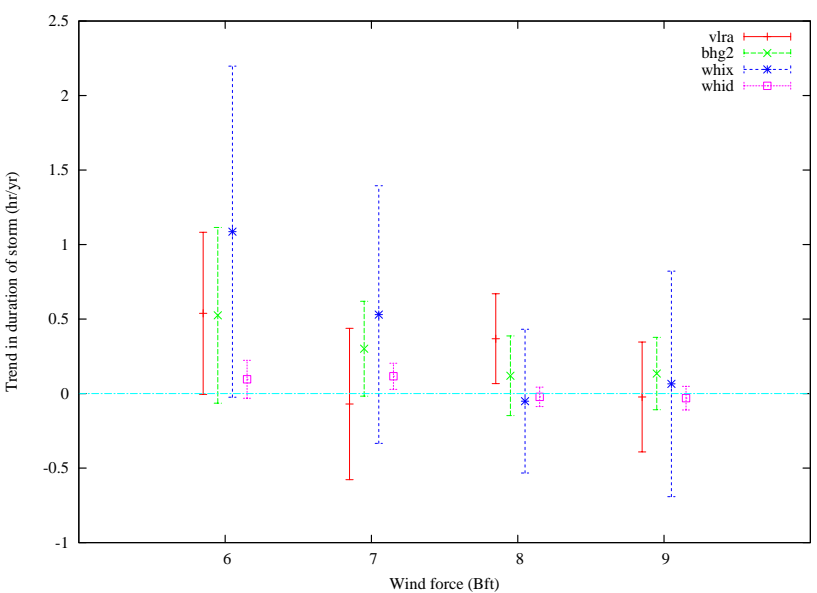

Fig. 4. Trend in the duration of the storms for the difference in wind forces. vlra: Vlakte van de Raan; bhg2: Brouwershavensegat 2; whix: Westhinder; whid: Westhinder DNMI data. The error bars give the $95 \%$ confidence interval.

Monthly means of the significant wave height were, as previously described in Sect. 3.2.1, calculated and split in a long-term trend (moving average filter over 48 months), a seasonal cycle and a residue (Visser et al., 1996). In the long-term trend, a clear variability with a period of about $7 \mathrm{yr}$ is apparent, with higher waves around 1987, 1994 and 2001. The period is related to the North Atlantic Oscillation (NAO) which shows variations with periods of $17 \mathrm{yr}, 7.7 \mathrm{yr}$ and $2.4 \mathrm{yr}$ (Loewe and Koslowski, 1994). A clear long-term trend in the significant wave heights is, however, not visible.

\subsubsection{Trends in changes of frequency of high waves}

The trend in yearly frequency of occurrence for different significant wave heights were analysed for the four time series. Also for the waves, the same procedure as above is followed to avoid the influence of missing data. The results are presented in Fig. 5. 


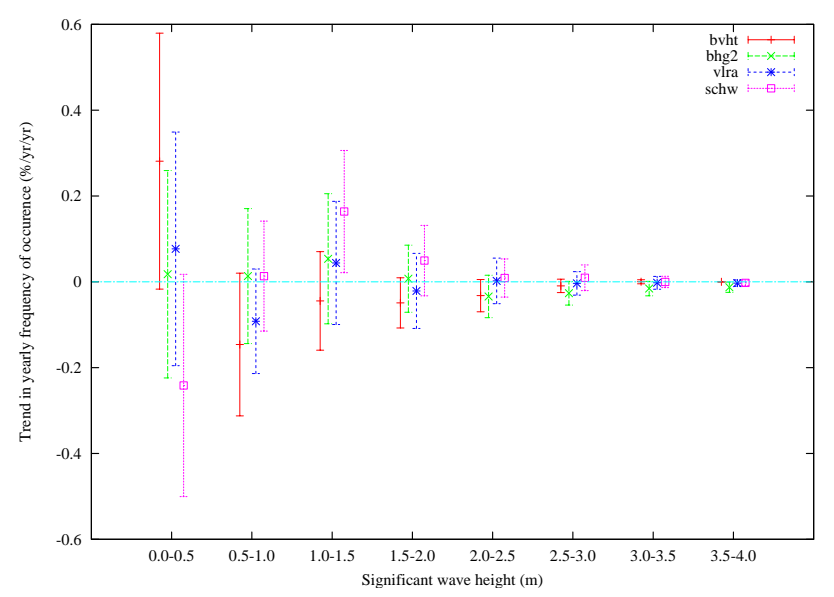

Fig. 5. Trend in the yearly frequency of occurrence for the different significant wave heights. bvht: Bol van Heist; bhg2: Brouwershavensegat 2; vlra: Vlakte van de Raan; schw: Scheur West. The error bars give the $95 \%$ confidence interval.

Results seem to indicate that more waves between 1 and $1.5 \mathrm{~m}$ and fewer waves between 0.5 and $1 \mathrm{~m}$ are observed, but these results are not statistically significant, except for the increase in waves between 1 and $1.5 \mathrm{~m}$ at Scheur West. For higher values, there is a statistically significant decrease in frequency of occurence of waves higher than $3.5 \mathrm{~m}$ at Brouwershavensegat $2\left(-0.013 \% \mathrm{yr}^{-2}\right)$. This trend is, however, very small. Also here, one can conclude that no statistically significant trend can be detected in the occurrence of higher waves over the last decades.

\section{Conclusions}

Sea-level rise was estimated at $1.69 \mathrm{~mm} \mathrm{yr}^{-1}$ over the last $80 \mathrm{yr}$, using a conventional linear regression technique. The present sea level rise lies close to $4.41 \mathrm{~mm} \mathrm{yr}^{-1}$. IMDC published the hydraulic boundary conditions for the Belgian coast in 2005. A relative rise of the mean sea level of $22 \mathrm{~cm}$ is to be expected in the coming $50 \mathrm{yr}$ (2005 to 2055) and this should be taken into account for new constructions being built along the Belgium coast.

Ullman and Monbaliu (2010) indicate that the yearly averaged surge levels at the Belgian coast and extreme surge levels are rising. However, based on results of global climate models, the surge levels are not expected to increase in the 21th century (Ullmann et al., 2009).

In the present study, no clear trend could be observed for the occurrence of higher wind speeds nor increased frequency or duration of storm winds over the BPNS. Other recent literature (from the Netherlands or Germany) does not yield a clear response either. Similarly, no clear trend could be demonstrated for the occurrence of higher waves.
Literature sources do not yield a clear view and do not give information that is ready to be implemented in a climate change scenario. Based on the results presented in this paper, there is currently not enough scientific evidence to support a scenario with increased storminess for the Belgian coast. There are no design guidelines yet for incorporating climate change induced changes in extreme wind or waves or changes in intensity and duration of storms. It is, therefore, concluded that based on the results presented in this study, not enough scientific proof is available to change the hydraulic boundary conditions (waves and wind) in the definition of coastal protection or management plans for the Belgian coast.

Acknowledgements. The research was executed in the framework of the CLIMAR project, which was executed for the Belgian Science Policy under the contract SD/NS/01 and in the framework of the MICORE project (no. 202798) under the European FP7 programme. José Ozer, Fabrice Ovidio and Frederic Francken are thanked for their useful input. The authors thank the MDK for making wind and significant wave height data available for their research. The authors acknowledge the constructive remarks of two anonymous reviewers that significantly improved the quality of the paper.

Edited by: J. A. Jimenez

Reviewed by: two anonymous referees

\section{References}

Bijl, W., Flather, R., de Ronde, J. G., and Schmith, T.: Changing storminess? An analysis of long-term sea level data sets, Clim. Res., 11, 161-172, 1999.

Bindoff, N. L., Willebrand, J., Artale, V., Cazenave, A., Gregory, J., Gulev, S., Hanawa, K., Le Quéré, C., Levitu, S., Nojiri, Y., Shum, C. K., Talley, L. D., and Unnikrishnan, A.: Observations: Oceanic Climate Change and Sea Level. In: Climate Change 2007: The Physical Science Basis, Contribution of Working Group I to the Fourth Assessment Report of the Intergovernmental Panel on Climate Change, edited by: Solomon, S., Qin, D., Manning, M., Chen, Z., Marquis, M., Averyt, K. B., Tignor, M., and Miller, H. L., Cambridge University Press, Cambridge, United Kingdom and New York, NY, USA, 2007.

Church, J. A. and White, N. J.: A 20th century acceleration in global sea level rise, Geophys. Res. Lett., 33, L01602, doi:10.1029/2005GL024826, 2006.

Debenard, J. and Roed, L. P.: Future wind, wave and storm surge climate in the Northern Sea: a revisit, Tellus, 60, 427-438, 2008.

European Commission, Directorate General, Joint Research Centre: Marine and coastal dimension of climate change in Europe, A report to the European Water Directors, Institute for Environment and Sustainability, 2006.

Haerens, P., Bolle, A. Trouw, K., and Houthuys, R.: Definition of storm thresholds for significant morphological change of the sandy beaches along the Belgian coastline, Geomorphology, in press, doi:10.1016/j.geomorph.2011.09.015, 2011. 
Holgate, S. J. and Woodworth, P. L.: Evidence for enhanced coastal sea level rise during the 1990's, Geophys. Res. Lett., 31, L07305, doi:10.1029/2004GL019626, 2004.

IMDC: Hydraulische randvoorwaardenboek Vlaamse kust. IMDC in opdracht van het Ministerie van de Vlaamse Gemeenschap, Departement Leefmilieu en Infrastructuur, Administratie Waterwegen en Zeewezen, Afdeling Waterwegen Kust, 2005.

IPCC: Third Assessment Report: Climate Change 2001: Synthesis Report + Contribution of Working Group I: The Science of Climate Change + Contribution of Working Group II: Impacts, Adaptation and Vulnerability + Contribution of Working Group III: Mitigation of Climate Change, 2001.

Jungclaus, J. H., Bozet, M., Haak, H., Keenlyside, N., Luo, J. J., Latif, M., Marotzke, J., Mikolajewicz, U., and Roecknet, E.: Ocean circulation and tropical variability in the coupled model ECHAM5/MPI-OM, J. Climate, 19, 3952-3972, 2006.

Katsman C., Hazeleger, W., Sterl, A., and Beersma, J.: Exploring high-end scenario's for flood protection of the Netherlands, Conference Climate change: global risks, challenges and decisions, Copenhagen, March 2009, IOP Conference series: Earth and Environmental Science, 6, 352004, 2009.

Loewe, P. and Koslowski, G.: The western Baltic sea ice season in terms of a mass-related severity index: 1879-1992, Part II: Spectral characteristics and associations with the NAO, QBO and solar cycle, Tellus, 50A, 219-241, 1994.

Lowe, J., Tinker, J., Howard, T., De Gusmao, D., Wolf, J., Horsburgh, K., Holt, J., and Reeder, T.: Informing adaptation: a new set of marine climate change scenario's, Conference Climate change: global risks, challenges and decisions. Copenhagen, March 2009, IOP Conference series: Earth and Environmental Science, 6, 352002, 2009.

Metreveli, G. S., Plotk'na, I. G., and Kuchuashvili, N. K.: Calculating rates of secular fluctuations of sea level and land surface according to level series, Soviet Meteorology and Hydrology, 2, 68-72, 1985.

MICORE: Review of climate change impacts on storm occurrence, Work package 1, FP7 Project 202798, Deliverable 1.4, 125 pp., 2009.

MIRA: Milieurapport Vlaanderen, achtergronddocument klimaatverandering 2007, Brouwers, J., De Nocker, L., Schoeters, K., Moorkens, I., Jespers, K., Aernouts, K., Beheydt, D., and Vanneuville, W., Vlaamse Milieumaatschappij, april 2008, 224 pp., available at: www.milieurapport.be, 2008.

OSPAR Commission: Quality Status Report 2000, Region II Greater North Sea, OSPAR Commission, London, $136+$ xiii pp., 2000

Reistad, M. and Iden, K.: Updating, correction and evaluation of a hindcast data base of aire pressure, wind and waves for the North Sea, the Norwegian Sea and the Barents Sea, The Norwegian Meteorological Institute, Research Report No. 9, 42 pp., 1998.

Siegismund, F. and Schrum, C.: Decadal changes in the wind forcing over the North Sea, Clim. Res., 18, 39-45, 2001.

Smits, A., Klein Tank, S. M. G., and Können, G. P.: Trends in storminess over the Netherlands, 1962-2002, Int. J. Climatol., 25, 1331-1344, 2005.
Sterl, A., Severijns, C., van Oldenborgh, G. J., Dijkstra, H., Hazeleger, W., van den Broeke, M., Burgers, G., van der Hurk, B., van Leeuwen, P. J., and van Velthoven, P.: When can we expect extremely high surface temperatures?, Geophys. Res. Lett., 35, L14703, doi:10.1029/2008/GL034071, 2008.

Ullmann, A. and Monbaliu, J.: 21th century surge-height variability along the Belgian coast under A1b SRES scenario, Poster presented at the Interdisciplinary SEAMOCS Workshop Effects of climate change: coastal systems, policy implications and the role of statistics, Sliema, Malta, 18-20 March 2009, 2009.

Ullmann, A. and Monbaliu, J.: Changes in atmospheric circulation over the North Atlantic and sea-surge variations along the Belgian coast during the twentieth century, Int. J. Climatol., 30, 558-568, 2010.

Ullmann, A., Van den Eynde, D., Sterl, A., and Monbaliu, J.: Contemporary and future climate variability and climate change: Impacts on sea-surge and wave height along the Belgian coast, Katholieke Universiteit Leuven, Hydraulics Laboratory, Internal Report, 54 pp., 2009.

Van Cauwenberge, C.: Relative sea level rise: further analyses and conclusions with respect to the high water, the mean sea and the low water levels along the Belgian coast, Report nr 37ter of the Hydrografische Dienst der Kust, 1995.

Van Cauwenberghe, C.: Relative sea level rise along the Belgian coast: analyses and conclusions with respect to the high water, the mean sea and the low water levels, Report nr. 46 of the Hydrografische Dienst der Kust, 1999.

Van den Eynde, D., De Sutter, R., De Smet, L., Francken, F., Haelters, J., Maes, F., Malfait, E., Ozer, J., Polet, H., Ponsar, S., Reyns, J., Van der Biest, K., Vanderperren, E., Verwaest, T., Volckaert, A., and Willekens, M.: Evaluation of climate change impacts and adaptation responses for marine activities: CLIMAR, Final Report, Belgian Science Policy Office, Research Programme Science for a Sustainable Development, Brussels, 114 pp., 2011.

Van den Hurk, B., Klein Tank, A., Lenderink, G., van Ulden, A., van Oldenborg, G. J., Katsman, C., van den Brink, H., Keller, F., Bessembinder, J., Burgers, G., Komen, G., Hazelegers, W., and Drifthout, S.: KNMI new climate change scenarios for the Netherlands, Water Sci. Technol., 56, 27-33, doi:10.2166/wst.2007.533, 2007.

Visser, M., Batten, S., Becker, G., Bot, P., Colijn, F., Damm, P., Danielssen, D., Van den Eynde, D., Føyn, L., Frohse, A., Groeneveld, G., Laane, R., van Raaphorst, W., Radach, G., Schultz, H., and Sündermann, J.: Time series analysis of monthly mean data of temperature, salinity, nutrients, suspended matter, phytoand zooplankton at eight locations on the North-West European Shelf, Deutsche Hydrogr. Z., 48, 299-324, 1996.

Weisse, R., Von Storch, H., and Feser, F.: Northeast Atlantic and North Sea storminess as simulated by a regional climate model during 1958-2001 and comparison with observations, J. Climate, $18,465-479,2005$. 